\title{
Konsep Budaya Religius dalam Membangun Akhlakul Karimah Peserta Didik di Madrasah Ibtidaiyah
}

\author{
Jannah Ulfah ${ }^{1}$, Suyadi ${ }^{2}$ \\ Magister FITK UIN Sunan Kalijaga Yogyakarta ${ }^{1,2}$ \\ *e-mail: janahulfa9@gmail.com ${ }^{1}$, suyadi@uin-suka.ac.id ${ }^{2}$
}

\begin{abstract}
This study aimed to describe the concept of religious culture in building the morality of students in Islamic elementary schools. The moral crisis facing Indonesia today makes religious culture very important to be applied in the world of education that demands Islamic elementary school to build a morality of students. Religious culture in Islamic elementary schools is a way of thinking and acting based on religious values that underlie the behavior, traditions, and habits applied by all Islamic elementary school residents. This research is descriptive qualitative research that started from a literature study by searching various materials related to religious culture and morals. The study results can be discussed the form of religious culture that can be applied in Islamic schools. Several strategies can be used to build religion in building the morals of students in Islamic schools. In implementing religious culture, the active role, and support of various parties involving stakeholders as well. So that, religious culture can runs as expected, to wit can build students' morality
\end{abstract}

Keywords: religious culture, morality, islamic elementary school

(7) (5) Licensees may copy, distribute, display and perform the work and make derivative works and remixes based on it only if they give the author or licensor the credits (attribution) in the manner specified by these. Licensees may copy, distribute, display, and perform the work and make derivative works and remixes based on it only for non-commercial purposes.

\section{PENDAHULUAN}

Dewasa ini banyak peserta didik berperilaku kurang terpuji yang mengakibatkan masyarakat menjadi resah. Moralitas generasi muda akhir-akhir ini mengalami degredasi (Widodo, Suwandi, \& Saddhono, 2017 : 339). Degradasi moral menjadikan suatu bangsa mengalami keprihatinan yang sangat mendalam. Bangsa rapuh akibat hancurnya moral para pelajar. Di pundak pemudalah masa depan bangsa dipertaruhkan yang menjadi harapan bangsa (Suradarma, 2018). Indonesia saat ini mengalami tantangan yang sangat berat dalam dunia pendidikan, terutama untuk membentuk pribadi yang ber-akhlakul karimah. Sumber-sumber pembelajaran akibat globalisasi yang didukung oleh kemajuan teknologi mempercepat masuknya budaya asing sehingga mempengaruhi budaya, etika serta moral masyarakat Indonesia (Asrori, 2014).

Peran Pendidikan dalam hal ini sangatlah penting. Berdasarkan Undang Undang tentang Sistem Pendidikan Nasional No. 20 tahun 2003 pasal 1, Pendidikan adalah usaha sadar dan terencana untuk mewujudkan suasana belajar dan proses pembelajaran agar peserta didik secara aktif mengembangkan potesi dirinya untuk memiliki kekuatan spiritual keagamaan, pengendalian diri, kepribadian, kecerdasan, akhlak mulia, serta keterampilan yang diperlukan dirinya, masyrakat, bangsa, dan Negara (UU Sisdiknas, 2003). Pendidikan merupakan suatu kebutuhan mendasar bagi setiap manusia yang akan berlangsung sepanjang hidup sehingga menjadikan manusia bermartabat (A. Rahmawati, 2018 : 173).

Sekolah merupakan Lembaga Pendidikan untuk mengembangkan hubungan sosial dan sekaligus merupakan faktor lingkungan baru 
bagi individu. Tantangan saat ini semakin besar seiring dengan perkembangan zaman, dunia pendidikan dalam hal ini sangat berperan untuk mencetak generasi-generasi sumber daya manusia berkualitas yang nantinya akan menjadi pembaharu dimasa depan. Dalam menghadapi perkembangan zaman sumber daya manusia dituntut untuk terus ditingkatkan menjadi lebih baik, maka sudah seharusnya dilakukan peningkatan dalam mutu pendidikan (Rahmalia, Kardinah, \& Kurniadewi 2019 : 63).

Pendidikan diharapkan dapat memberikan kontribusi positif terkait moral masyarakat yang beradab. Untuk membangun bangsa Indonesia menjadi lebih baik maka lembaga pendidikan harus mampu mencetak generasi yang bermoral. Peserta didik diarahkan bukan hanya unggul intelektual saja, akan tetapi juga diharapkan memiliki tingkah laku yang baik (Lubis, 2018). Kedua komponen ini jika dapat diterapkan dengan baik dalam dunia pendidikan maka akan mencetak generasi bangsa Indonesia yang berkualitas. Krisis moral yang melanda bangsa ini menjadi suatu kecemasan di berbagai kalangan. Keadaan ini menjadi kompleks dengan adanya beberapa perilaku negatif yang tidak patut untuk di contoh seperti korupsi yang tidak pernah surut, tawuran antar pelajar, pergaulan bebas, penganiayaan, pembunuhan, penggunaan obat terlarang, dan perilaku negatif lainnya. Peristiwa tawuran antar pelajar yang terjadi di Kota Depok dipicu dengan adanya saling mengejek, saling meludah sehingga terjadinya tawuran dan mengakibatkan beberapa siswa luka parah dan satu korban tewas (Ulumudin 2016 :45).

Fenomena tersebut sangat memprihatinkan dan bertolak belakang dengan kepribadian dan budaya bangsa Indonesia. Jika dianggap sesuatu yang biasa dan dibiarkan begitu saja kebejatan moralitas seperti ini maka akan menjadi budaya yang dapat melemahkan nilai-nilai dalam kehidupan bernegara dan berbangsa. Pada dasarnya budaya religius yang diterapkan di sekolah membina perilaku dan sikap keagamaan peserta didik. Dalam budaya religius yang diutamakan bukan hanya sekedar pengetahuan akan tetapi mampu mempraktekkan dan menjalani hidup atas dasar ajaran agama.
Melihat begitu pentingnya pelajaran pendidikan agama islam agar perilaku keagaamaan ada dalam diri peserta didik, maka guru sebaiknya harus lebih intens dalam mengajarkan agama kepada peserta didik dengan berbagai macam metode agar setiap pesan moril yang disampaikan kepada peserta didik dapat terwujud dengan baik (Zedan, Yusoff, dan Mohamed., 2015). Beberapa metode untuk diterapkan oleh guru supaya perilaku keagamaan dimiliki peserta didik diantaranya dengan membiasakan budaya religius. Budaya religius atau budaya keagamaan merupakan tradisi yang dilakukan oleh seluruh warga madrasah yang diterapkan di madrasah berdasarkan nilai-nilai religius (keagamaan) yang tercipta dari tingkah laku, tradisi, kebiasaan, keseharian, dan symbolsimbol yang diterapkan oleh seluruh warga madrasah. Upaya yang dapat dilakukan dalam membangun akhlaku karimah peserta didik diantaranya dengan membiasakan budaya religius atau budaya keagamaan di lingkungan madrasah (Pratama \& Siraj ,2019 : 334).

Pembiasaan budaya religius ini seyogyanya harus dimulai.dari sekolahsekolah, khususnya madrasah. Dimana madrasah dalam menanamkan nilai-nilai keislaman lebih tinggi dalam pertanggung jawaban mendidik supaya peserta didik berakhlakul karimah di lingkungan keluarga maupun masyarakat. Menurut Kurniawan (2013 : 128) kegiatan religius yang diajarkan kepada peserta didik di sekolah dapat dijadikan sebagai pembiasaan. Dalam pelaksanaan budaya religius tidak dapat terbentuk begitu saja, akan tetapi dengan pembiasaan dan kegiatan sehari-hari. Adanya budaya religius di madrasah sangat diharapkan dapat membangun akhlakul karimah peserta didik.

Masa anak-anak merupakan pondasi lanjutan dari masa usia dini dalam menanamkan nilai agama-moral sebagai bekal kehidupan (Nabilah, Khoiriah, \& Suyadi, 2019 : 193). Sehingga pembiasaan budaya religius sangat penting untuk diterapkan di Madrasah Ibtidaiyah (MI), karena MI merupakan pondasi awal untuk membekali peserta didik memiliki akhlakul karimah di masa yang akan datang. Dari pemaparan tersebut di atas, maka tujuan dari penelitian ini adalah untuk mendeskripsikan konsep budaya religius dalam 
membangun akhlakul karimah peserta didik di Madrasah Ibtidaiyah (MI).

\section{PEMBAHASAN}

\section{Budaya Religius dan Akhlakul Karimah}

Budaya religius berasal dari dua kata yaitu "budaya" dan "religius". Budaya secara etimologi berarti kebudayaan. Kata budaya atau kebudayaan berasal dari Bahasa sansekerta yaitu buddhayah bentuk jama' dari buddhi (budi atau akal) memiliki arti segala sesuatu yang berhubungan dengan akal pikiran manusia. Segala sesuatu yang berupa hasil dari cipta, rasa, dan karsa manusia dalam bermasyarakat di sebut kebudayaan. Dalam Bahasa latin terdapat istilah yang memiliki makna sama dengan budaya yaitu "colere" yang biasa di sebut kultur memiliki makna mengerjakan atau mengolah, jadi semua tindakan manusia untuk mengolah atau mengerjakan sesuatu di sebut kultur atau budaya. (Komariah 2016).

Berdasarkan Kamus Besar Bahasa Indonesia budaya berarti pikiran, adat istiadat, yaitu segala macam kebiasaan yang telah berkembang di masyarakat dan menjadi tradisi sehingga tidak mudah merubahnya (Depdiknas, 1991). Menurut Muhammad Fathurrahman budaya adalah sesuatu yang terlahir pembiasaan dan pemikiran yang menjadi ciri khas dari suatu kelompok masyarakat. Budaya dapat juga diartikan sebagai segala sesuatu yang diterima oleh suatu masyarakat berupa hasil cipta, karya dan karsa manusia yang diterapkan dalam kehidupan sehari-hari dengan penuh kesadaran tanpa pemaksaan dan diwariskan pada generasi selanjutnya (Fathurrohman, 2015 : 48). Berdasarkan beberapa pengertian budaya di atas dapat diambil kesimpulan bahwa budaya adalah suatu pandangan hidup atau norma kebiasaan berupa nilai-nilai yang terlahir dari hasil cipta, rasa, dan karsa di lingkungan masyarakat yang dilaksanakan dalam kehidupan sehari-hari.

Setelah memaparkan arti dari budaya, selanjutnya penulis akan memaparkan arti dari religius. Dalam Kamus Besar Bahasa Indonesia religius berarti bersifat keagaaman, terkait dengan kepercayaan agama (Bagus Pratama, 2015 : 377). Menurut ajaran islam religius berarti melaksanakan ajaran agama secara menyuluh. Suatu kepercayaan baik dalam bentuk agama maupun non agama pasti dimiliki oleh setiap orang. Religius merupakan suatu perilaku dan sikap yang dimiliki oleh seseorang yang taat dalam melaksanakan ajaran agama yang di anutnya, dan mempunyai sikap toleran terhadap orang lain yang melaksanakan ibadah berbeda dengan keyakinannya serta hidup rukun dengan yang berbeda agama (Amri Syafri, 2012).

Nucholish Madjid, merupakan salah satu intelektual muslim berpendapat bahwa agama tidak hanya percaya kepada yang ghaib dan menjalankan ibadah tertentu. Akan tetapi, Agama merupakan perilaku terpuji yang di lakukan oleh umat muslim hanya untuk memperoleh ridho Allah SWT. Dapat dikatakan bahwa agama mencakup keseluruhan perilaku manusia dalam hidup. Perilaku tersebut akan menjadikan manusia yang berbudi pekerti luhur (akhlakul karimah) dengan di dasari percaya atau iman kepada Allah dan bertanggung jawab atas diri pribadi masing-masing di kemudian hari (Naim, 2012). Dari beberapa pengertian religius diatas dapat disimpulkan bahwa pengertian religius merupakan suatu dasar percaya atau iman kepada Allah yang dinyatakan dengan menjalankan perintah agama secara meyeluruh yang merupakan tanggung jawab pribadi, sehingga seluruh perilakunya di landasi dengan keimanan kepada Allah dan terbiasa berperilaku baik.

Terkait dengan pengertian budaya dan religius, maka budaya religius dapat diartikan sebagai tradisi yang memiliki nilai-nilai ajaran agama yang di laksanakan dalam kehidupan sehari-hari. Dengan menerapkan budaya agama di madrasah maka secara sadar maupun tidak ketika seluruh warga madrasah mengikuti budaya yang telah tertanam, maka warga madrasah sebenarnya telah melaksankan ajaran agama. Dalam komunitas sekolah budaya religius tidak hanya menjalankan sholat berjama'ah, membaca Al-Qur'an, melakukan amalan yang berhubungan dengan rukun islam saka, akan tetapi melaksanakan juga budaya 5S, yaitu: senyum, sapa, salam, sopan, dan santun. Selain itu di perhatikan juga proses pembelajarannya, tertib, disiplin, jujur, adil, toleran, empati, simpati, membuang sampah pada tempatnya, kebersihan dan keindahan 
lingkungan madrasah di jaga, parkir kendaraan di tempatnya dan perilaku positif lainnya (Putra, 2017 : 26).

Akhlakul karimah berasal dari dua kata yaitu "akhlak" dan "karimah". Kata "akhlak" berasal dari Bahasa Arab, jamak dari khuluqun, yang menurut Bahasa berarti budi pekerti, perangai, tingkah laku, atau tabiat. Akhlak dalam kamus besar Bahasa Indonesia berarti budi pekerti, perilaku (Bagus Pratama, 2015 : 19). Chabib Thoha mengutip pendapat dari Imam Al-Ghazali berpendapat bahwa akhlak merupakan sifat yang tertanam dalam jiwa manusia yang menimbulkan perbuatan yang dilakukan secara spontan dengan tidak mempertimbangkan pemikiran terlebih dahulu (Ilyas ,2012:1-2).

Akhlak merupakan suatu kata yang tidak bisa dilepaskan pada diri seseorang. Akhlak yang tertanam inilah yang akan menjadi perangai bagi seseorang dalam bertingkah laku sehari-hari yang berasal dari hati, bukan pikiran. Jika sesorang memiliki hati yang baik, maka akhlaknya pun akan menjadi baik. Akan tetapi, jika hatinya buruk, maka cenderung akan melakukan perbuatan yang buruk diluar norma yang berlaku di masyarakat. Jadi akhlak merupakan tata perilaku, sikap maupun tabiat seseorang terhadap orang lain dan lingkungannya yang dapat melahirkan berbagai macam perbuatan baik dan buruk.

Kata karimah berasal dari Bahasa arab yaitu karoma-yakromu-karoman yang memiliki arti mulia, murah hati, dan dermawa (Yunus, 1973: 73). Sedangkan dalam Kamus Besar Bahasa Indonesia karima memiliki arti baik dan terpuji (Daryanto, 2010 : 329). Karimah adalah kata yang digunakan untuk menunjukkan pada perbuatan dan akhlak yang terpuji dalam kenyataan hidup sehari-hari. Akhlakul karimah merupakan perilaku terpuji yang lahir dari sifat-sifat baik yang selalu identik dengan keimanan dan perbuatan yang baik lagi terpuji serta tidak bertolak belakang dengan hukum syarak' dan akal fikiran yang sehat (Hawi, 2014).

Akhlakul karimah dalam menjalani kehidupan sangat diperlukan, karena dengan berkhlakul karimah kita akan mudah diterima oleh masyarakat dan sebagai bekal hidup untuk hidup damai di dunia maupun di akhirat. Dalam dunia pendidikan pembentukan akhlakul karimah ini bertujuan agar peserta didik tidak berperilaku menyimpang. Sehubungan dengan akhlakul karimah di atas, banyak dalam ayat-ayat Al-Qur'an dan Hadits Nabi yang dijadikan dasar hokum akhlak diantaranya yaitu: (1) Ayat Al-Qur'an yang menjadi sumber hukum akhlak yaitu yang berbunyi:

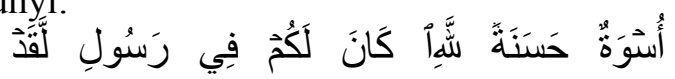

Artinya: "Sesungguhnya telah ada pada diri Rasulullah itu suri tauladan yang baik bagimu..(QS. Al-Ahzab :21); (2) Hadist Nabi yang menjadi dasar hukum akhlak yaitu hadits dari Abu Hurairah r.a bahwasanya Rasulullah SAW bersabda yang berbunyi:

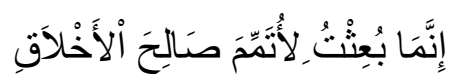

Artinya: "Sesungguhnya Aku diutus ke muka bumi adalah untuk menyempurnakan akhlak yang baik". (HR. Ahmad)

Berdasarkan ayat Al-Qur'an dan Hadits Nabi diatas dapat kita lihat bahwasanya Rasulullah SAW merupakan sentral peneladanan bagi umat manusia sebagai penghantar bagi manusia menuju jenjang kehidupan yang bahagia dan sejahtera. Tidak bisa dipungkiri bahwsanya jiwa manusia memiliki dua fitrah yaitu baik dan buruk. Fitrah yang baik menghantarkan manusia kepada kebaikan yang akan membawa kebermanfaatan dalam kehidupan seseorang, jiwanya akan merasa senang dapat menemukan dan melaksanakan kebaikan maka inilah yang dinamakan akhlakul karimah. Sedangkan fitrah yang buruk akan menyeret manusia keluar dari jalur yang benar, sehingga menimbulkan perbuatan yang menimbulkan bencana bagi manusia dan dapat menjerumuskan manusia ke jurang kebinasaan inilah yang disebut dengan akhlak yang buruk (Mucharomah, 2017 : 154155).

Pembentukan akhlakul karimah dipengaruhi oleh dua faktor yaitu : 1) faktor dari dalam (internal), mencakup pembawaan si anak yang terdiri dari latar belakang kognitif (pemahaman ajaran agama, kecerdasan), latar belakang afektif (motivasi, minat, sikap, bakat, konsep diri dan kemandirian). Disini akhlak manusia terbentuk dengan dipengaruhi pengetahuan agama yang dimiliki dan pergaulannya sehari-hari dalam hidup 
bermasyarakat; 2) factor ekternal, yaitu merupakan suatu aspek yang turut andil untuk membentuk sikap dan perilaku manusia. Beberapa aspek tersebut diantaranya lingkungan Pendidikan, lingkungan keluarga, sekolah dan masyarakat (Rusmaini, 2011 : 1213). Sedangkan menurut Nabilah (2019 :129) terdapat tiga faktor pendukung yaitu:1) faktor internal/dalam diri anak; 2) faktor keluarga/lingkungan; dan 3) faktor lingkungan sekolah.

Akhlakul karimah dapat dibagi berdasarkan sifat dan objeknya. Akhlak berdasarkan sifatnya terbagi menjadi dua, yaitu akhlakul karimah ( akhlak terpuji) dan akhlak mazmumah (akhlak tercela). Akhlakul karimah meliputi: ridha Allah, cinta dan beriman kepada Allah, beriman kepada malaikan Allah, kitab, rasul, hari kiamat, dan takdir Allah SWT, taat beribadah, selalu menepati janji, melaksanakan amanah, berperilaku sopan dalam ucapan dan perbuatan, qana'ah (rela menerima pemberian Allah SWT.), tawakal, sabar, syukur, tawadhu', dan segala perbuatan yang baik menurut Al-Qur'an dan Sunnah (Rosihon Anwar, 2008: 212-213). Akhlakul karimah berdasarkan objeknya yaitu merupakan suatu landasan dalam hidup manusia yang dijadikan sebagai pengatur hubungan antara manusia dengan sang pencipta yaitu Allah SWT, manusia dengan manusia, dan manusia dengan alam (Amri Syafri, 2012 : 79).

\section{Bentuk-bentuk Budaya Religius dalam Membangun Akhlakul Karimah Peserta Didik di Madrasah Ibtidaiyah (MI)}

Budaya Religius merupakan pembiasaan-pembiasaan di sekolah yang memiliki nilai agama untuk membangun akhlakul karimah yang dijalankan oleh seluruh warga sekolah. Terdapat beberapa bentuk budaya religius yang dapat diterapkan di madrasah ibtidaiyah dalam membangun akhlakul karimah peserta didik. Menurut Sahlan (2017: 132-135) ada 4 budaya religius yang dapat diterapkan yaitu : (1) senyum, salam, sapa (3S), sapaan dengan mengucapkan salam dengan senyum kepada orang lain saat berpapasan di jalam merupakan sesuatu yang sangat dianjurkan Islam; (2) saling hormat dan toleran, dalam islam orang tua dan guru sangat dihormati. Oleh karena itu, peserta didik harus dibiasakan memiliki rasa hormat dan toleran kepada sesama terutama kepada orang tua dan guru; (3) Sholat dhuha, Syekh Musthafa menjelaskan bahwa shalat adalah sarana terbaik dalam mendidik dan mensucikan akahlak. Shalat dhuha merupakan sholat sunnah yang dikerjakan diwaktu matahari sedang naik. Waktu shalat dhuha ini diperkirakan ketika matahari sedang naik kurang lebih setinggi 7 hasata (pukul 7 sampai sebelum dzuhur) (Rifa'i, 2004 : 84-85).

Pembiasaan sholat dhuha kepada peserta didik ini dapat berimplikasi pada spritualitas dan mentalitas sehingga terbangun akhlakul kalrimah pada diri peserta didik; (4) Tadarus Al-Qur'an atau membaca Al-Qur'an merupakan salah satu pembiasaan untuk meningkatkan keimanan, ketaqwaan, serta mendekatkan diri peserta didik kepada Allah SWT. Tadarus Al-Qur'an dapat menumbuhkan rasa cinta peserta didik terhadap Al-Qur'an dan juga dapat menumbuhkan sikap positif sehingga berpengaruh pada meningkatnya prestasi belajar dan akhlak peserta didik serta sebagai benteng untuk terhindar dari budaya negatif.

Berkaitan dengan hal tersebut, dalam penelitian Wasito dan Turmudi ( 2018 : 6-12) terdapat 7 temuan budaya religius diantaranya: 1) Belajar membaca, menulis Al-Qur'an dan menghafal juz amma, 2) Pemakaian busana muslim, 3) Pelaksanaan sholat jama'ah di sekolah, 4) Pembiasaan senyum, sapa, salam, 5) Program madin yaitu program madrasah diniyyah, materi yang diajarkan adalah menulis Bahasa Indonesia dengan menggunakan huruf arab untuk melatih peserta didik dalam menulis arab dan membaca tulisan pegon yang banyak ditulis oleh kalangan santri, 6) Do'a Bersama, 7) kegiatan seni dan kegiatan yang bernuansa islam seperti lomba da'I cilik, lomba hafalan surat-surat dan lomba lainnya yang dapat mengembangkan bakat siswa dan mengenalkan siswa pada seni keislaman.

Selain budaya religius diatas, ada beberapa bentuk wujud budaya religius yang dapat di terapkan dimadrasah ibtidaiyah (MI) yaitu: 1) Bersalaman dan mengucapkan salam kepada guru, 2) Sholat dhuha berjamaah, 3) Pembacaan Asmaul Husna dan pembinaan baca Al-Qur'an, 4) mengucapkan salam saat 
memasuki ruangan, 5) Berdo'a sebelum dan sesudam pembelajaran, 6) Sholat dzuhur dan sho;at jum'at berjama'ah, 7) Mengaji sesuai jilid, 8) Tidak membuang sampah sembarangan, 9) Makan dan minum dengan tangan kanan dan dengan duduk, 9) Pembiasaan Infaq setiap jum'at, 10) Peringatan Hari Besar Islam (PHBI) seperti: peringatan maulid nabi dan peringatan tahun baru hijriah (Rahmawati, Afifulloh, \& Sulistiono, 2019: 139-141).

Berdasarkan beberapa budaya religius di atas, dapat di tarik kesimpulan bahwa terdapat banyak bentuk budaya religius yang dapat diterapkan di masdrasah ibtidaiyah (MI) untuk membangun akhlakul karimah pserta didik. Dalam membangun dan membentuk akhlakul karimah peserta didik ini tidak dapat dicapai dengan cara yang instan. Oleh karena itu, pembiasaan budaya religius harus dilakukan setiap hari agar akhlak peserta didik dapat terbangun dengan baik sesuai dengan yang diharapkan.

\section{Strategi untuk Mewujudkan Budaya Religius dalam Membangun Akhlakul Karimah Peserta Didik di Madrasah Ibtidaiyyah (MI)}

Strategi merupakan cara yang digunakan untuk mewujudkan budaya religius dalam membangun akhlakul karimah peserta didik di madrasah ibtidaiyah (MI). Berikut beberapa cara yang dapat digunakan untuk mewujudkan budaya religius daalam membangun akhlakul karimah peserta didik di madrasah ibtidaiyah (MI) menurut Mulyadi (2018: 8-9) yaitu: Pertama, guru sebagai pendidik harus memiliki ketrampilan untuk mengembangkan budaya religius madrasah untuk dilakasanakan setiap hari dalam proses pembelajaran secara rutin. Kegiatan ini di program dengan baik supaya peserta didik dapat menjalankan program tersebut. Dalam hal ini program budaya religius bukan hanya aspek pengetahuan saja, namun juga harus di terapkan, hal tersebut terdiri dari beberapa aspek yaitu pembentukan sikap, perilaku, dan pengalaman keagamaan sehingga tercetak generasi bangsa yang berakhlakul karimah.

Kedua, menyampaikan pendidikan agama sebagai upaya menciptakan budaya agama di lingkungan lembaga pendidikan.
Lingkungan mempunyai peran sangat penting dalam konteks pendidikan yaitu mengenai penanaman dan pemahaman nilai keagamaan. Budaya religius di madrasah dapat ditumbuhkan dengan adanya suasana yang nyaman, sehingga dapat membimbing peserta didik berakhlakul karimah, disiplin, berperilaku jujur, dan memiliki semangat tinggi yang menjadi landasan dalam meningkatkan kualitas diri peserta didik.

Ketiga, budaya religius selain disampaikan secara formal oleh guru dalam proses pembelajaran, disampaikan juga secara non formal. Dalam hal ini guru sebagai pendidik dapat memberikan pendidikan agama secara spontan saat menangani peserta didik yang berperilaku tidak sesuai dengan ajaran agama. Pendidikan yang diterapkan seperti ini memiliki manfaat yaitu peserta didik memiliki kepekaan dalam menyadari kesalahannya dan segera memperbaiki kesalahannya. Sehingga peserta didik dapat mengambil pelajaran mengenai perilaku baik dan perilaku buruk.

Keempat, guru menciptakan suasana yang religius. Diciptakannya suasana seperti ini yaitu bertujuan untuk memperkenalkan kepada peserta didik terkait dengan pemahaman dan tata cara pelaksanaan ajaran agama islam untuk dapat diamalkan dalam kehidupan sehari-hari. Oleh sebab itu, pembiasaan budaya religius budaya religius dapat diciptakan di madrasah dengan cara menyediakan peralatan untuk peribadatan peserta didik, seperti tempat shalat (masjid atau mushola), peralatan sholat. Kemudian di dalam ruang kelas dihiasi dengan kaligrafi, sehingga peserta didik terbiasa melihat sesuatu yang baik. Seorang guru juga harus menjadi tauladan bagi peserta didiknya, seperti selalu mengucapkan salam ketika akan memulai atau mengakhiri pelajaran dan saat bertemu guru ataupun teman sebayanya.

Kelima, guru memberikan kesempatan kepada peserta didik untuk dapat mengekspresikan diri, menumbuhkan bakat, minat dan kreativitas dirinya. Selain itu, guru mengadakan kegiatan yang dapat menumbuhkan akhlakul karimah pada diri peserta didik, seperti membaca Al-Qur'an dengan, membaca asma'ul husna, dan kegiatan positif lainnya. Dalam hal ini peran guru sangan penting. Menurut Suyadi (2014 : 123) 
guru memiliki peran yang sangat sentral dan strategis dalam membentuk karakter yaitu sebagai pembimbing bagi peserta didik.

Keenam, guru mengadakan beberapa macam bentuk lomba keagamaan, seperti cerdas cermat untuk membiasakan dan melatih keberanian, kecepatan, dan ketepatan dalam menyampaikan pengetahuan tentang materi pendidikan agama islam. Sebagian besar peserta didik menyukai perlombaan, karena dengan mengikuti perlombaan meraka akan menggali potensi yang dimilikinya. Kegiatan tersebut dapat menjadikan peserta didik untuk melaksanakan sesuatu yang bermanfaat, menambah pengetahuan, dan dapat mengembangkan kecerdasan, serta hasil belajar peserta didik akan tercapai dengan maksimal. Dalam perlombaan mengandung banyak nilai positif diantaranya peserta didik dapat membedakan mana yang baik dan yang buruk, sikap jujur, adil, amanah, mandiri dan berjiwa positif.

Ketujuh, menyelenggarakan kegiatan seni yang bernuansa keagamaan seperti nasyid, hadroh, dan seni lainnya. Seni merupakan suatu kegiatan dapat menumbuhkan ekspresi dan tanggapan sehingga menimbulkan kepekaan dalam diri peserta didik. Seperti kemampuan akademik, sosial, emosional, budaya, moral, dan kemampuan membangun spiritual (Naim, 2012 : 126-129). Menurut Baharuddin \& Suyadi (2020 : 9) agar peserta didik senang dalam belajar agama, teori pengkondisian klasik dapat digunakan yaitu untuk memotivasi peserta didik dalam belajar dan melatih peserta didik untuk melakukan kegiatan positif yang dapat mengembangkan potensi dalam dirinya.

Berbeda dengan pendapat diatas, menurut Muhaimin (2001 : 48-49) strategi untuk mewujudkan budaya religius dapat dilaksanakan dengan beberapa pendekatan, yaitu: (1) pendekatan struktural, yakni strategi yang digunakan agar terwujudnya budaya religius di sekolah yang menjadi prinsip dan kebijakan kepala sekolah, sehingga lahir berbagai peraturan yang mendukung adanya kegiatan keagamaan di sekolah.; (2) pendekatan formal, yaitu strategi yang digunakan untuk membiasakan budaya religius di madrasah melalui pengoptimlaan pembelajaran agama; (3) pendekatan mekanik, strategi ini dilandasi oleh pengertian bahwa terdapat beberapa aspek dalam kehidupan. Dalam hal ini pendidikan dipandang sebagai pondasi dalam mengembangkan seperangkat nilai-nilai dalam kehidupan. Pendekatan seperti ini akan terlaksana dengan meningkatkan kuantitas dan kualitas kegiatan ekstrakulikuler yang berkaitan dengan agama; (4) pendekatan organik, strategi ini berpandangan bahwa pendidikan agama merupakan bagian dari system madrasah yang berusaha memunculkan pandangan atau semangat hidup agamis yang dimanifestikan dalam sikap hidup, perilaku, dan keterampilan hidup yang religius.

Terdapat tambahan, yaitu ada tiga strategi lagi untuk membudayakan nilai-nili budaya religius, yaitu: (1) power strategy, strategi ini membudayakan nilai-nilai agama dengan cara memanfaatkan kekuasaan atau melalui people's power. Peran pimpinan dalam menetapkan kebijakan sangat dominan; (2) persuasive strategy, yakni strategi yang dilaksanakan melalui pembentukan opini dan pandangan masyarakat atau civitas akademik; (3) normative re-edecattive, norma diartikan sebagai aturan yang berlaku dimasyarakat (Naim 2012 : 129). Selain itu untuk mewujudkan budaya religius, para praktisi pendidikan melakukan usaha diantaranya: (1) menjadi contoh tauladan yang baik; (2) dibiasakan dengan hal positif; ditegakkannya kedisiplinan; (4) memberikan motivasi dan semangat; (5) memberikan apresiasi bagi peserta didik yang mengikuti kebijakan sekolah; (6) memberi peringatan bagi yang melanggar atauran; (7) diciptakannya suasana religius yang dapat mempengaruhi akhlak peserta didik (Tafsir $2004: 112$ ).

\section{KESIMPULAN}

Budaya religius merupakan suatu budaya yang sangat penting diterapkan di madrasah ibtidaiyah untuk membangun akhlakul karimah peserta didik. Madrasah Ibtidaiyah merupakan lembaga pendidikan yang bercirikan islam, karena itu harus mampu menciptakan budaya religius yang bersifat terus-menerus hingga warga madrasah memiliki kesadaran untuk melaksanakan nilai- 
nilai religius. Peran aktif dan dukungan dari berbagai pihak yang menjalankan maupun yang menjadi pemangku kebijakan dalam mengimplementasikan budaya religius sangat dibutuhkan, agar budaya religius dapat berjalan sesuai dengan yang diharapkan. Budaya religius yang tertanam kuat dalam diri semua warga madrasah merupakan sebuah solusi akan kebutuhan masyarakat terhadap lembaga pendidikan. Tidak hanya unggul dari segi intelektualnya saja, akan tetapi diharapkan mampu membangun akhlakul karimah sebagai benteng agar terhindar dari pengaruh negatif akibat perkembangan teknologi yang semakin maju.

\section{REFERENSI}

Amri Syafri, Ulil. (2012). Pendidikan Karakter Berbasis Al-Qur'an. Jakarta: Rajawali Pers.

Asrori, Achmad. (2014). "Pembentukan Akhlaqul Karimah Berbasis Pemaduan Sekolah dan Pesantren" Jurnal Studi Keislaman, 14 (2): 26.

Bagus Pratama, Aditya. (2015). Kamus Lengkap Bahasa Indonesia. Surabaya: Afifa Media.

Baharuddin, Baharuddin, and Suyadi Suyadi. (2020). "Implementation of The Classical Conditioning in PAI Learning." IJECA (International Journal of Education and Curriculum Application) 3 (1): 7.

Daryanto. (2010). Kamus Bahasa Indonesia Lengkap. Surabaya: Apollo Lestari.

Depdiknas .(1991). Kamus Besar Bahasa Indonesia. Jakarta: PT Balai Pustaka.

Fathurrohman, Muhammad. (2015). Budaya Religius Dalam Peningkatan Mutu Pendidikan: Tinjauan Teoritin Dan Praktik Kontekstualisasi Pendidikan Agama Islam Di Sekolah. Yogyakarta: Kalimedia.

Hawi, Akmal. (2014). Kompetensi Guru Pendidikan Agama Islam. Jakarta: PT Raja Grafindo Persada.

Ilyas, Yunahar. (2012). Kuliah Akhlak. Yogyakarta: Pustaka Pelajar Offset.

Komariah, Aan. (2016). Visionary Leadership: Menuju Sekolah Efektif. Jakarta: Bumi Aksara.
Kurniawan, Syamsul. (2013). Pendidikan Karakter: Konsepsi Dan Implementasinya Secara Terpadu Di Lingkungan Keluarga, Sekolah, Perguruan Tinggi, Dan Masyarakat. Yogyakarta: Ar-Ruzz.

Mucharomah, Miftah. (2017). "Kisah sebagai Metode Pendidikan Akhlak dalam Perspektif Al-Qur`an.” Edukasia Islamika, June, 146.

Muhaimin. (2001). Paradigam Pendidikan Islam: Upaya Mengefektifkan Pendidikan Agama Islam Di Sekolah. Bandung: PT. Remaja Rosdakarya.

Muhammad Yunus. (1973). Kamus ArabIndonesia. Jakarta: Penrjemah Penafsiran Al-Qur;an.

Mulyadi, Edi. (2018). "Strategi Pengembangan Budaya Religius di Madrasah." Jurnal Kependidikan 6 (1): 1-14.

Nabilah, Ifat. (2019). “Analisis Perkembangan Nilai Agama-moral Siswa Usia Dasar (tercapai) studi kasus di MI Ma'arif Bego." el-Ibtidaiy:Journal of Primary Education 2 (2): 106.

Nabilah, Ifat, Iswatun Khoiriah, and Suyadi Suyadi. (2019). "Analisis Perkembangan Nilai Agama-Moral Siswa Usia Dasar." TERAMPIL: Jurnal Pendidikan dan Pembelajaran Dasar 6 (2): 192-203.

Naim, Ngainun. (2012). Character Building Optimalisasi Peran Pendidikan dalam Pengembangna Ilmu dan Pembentukan Karakter Bangsa. Yogyakarta: Ar-Ruzz.

Pratama, Sandi, and Arifuddin Siraj. (2019). "Pengaruh Budaya Religius Dan Self Regulated Terhadap Perilaku Keagamaan Siswa" 08: 16.

Putra, Kristiya Septian. (2017). "Implmentasi Pendidikan Agama Islam Melalui Budaya Religius (Religious Culture) di Sekolah.” Jurnal Kependidikan 3 (2): 14-32.

Rahmalia, Putri, N Kardinah, and Elisa Kurniadewi. (2019). "Tipe Kepribadian Conscientiousness Dan Self-Regulated Learning Mahasiswa Dalam Menghafal Alquran Juz 30" 6 (2): 16.

Rahmawati, Ana. (2018). "Konsep Pembelajaran PAI bagi Anak Berkebutuhan Khusus di Sekolah Inklusi: Studi Kasus di SD Semai 
Jepara." Edukasia Islamika, December, 171.

Rahmawati, Fitriah, Muhammad Afifulloh, and Muhammad Sulistiono. (2019). "Penerapan Budaya Religius Dalam Meningkatkan Karakter Keagamaan Siswa di Min 2 Kota Malang" 1: 13.

Rifa'i, Moh. (2004). Risalah Tuntunan Shalat Lengkap. Semarang: PT. Karya Toha Putra.

Rosihon Anwar. (2008). Akidah Akhlak. Bandung: Pustaka Setia.

Rusmaini. (2011). Ilmu Pendidikan. Palembang: CV. Grafika Telindo.

Sahlan, Asma'un. (2017). Mewujudkan Budaya Religius Di Sekolah (Upaya Mengembangkan Teori Ke Aksi). Malang: Uin Maliki Press.

State College for Islamic Studies of Mandailing Natal, and Siti Hawa Lubis. (2018). "Islamic Religious Education (Pai) Learning Management in The Formation Of Student Characters At State Senior High School I Of Panyabungan." International Journal on Language, Research and Education Studies, 2 (3): 369-80.

Suradarma, Ida Bagus. (2018). "Revitalisasi Nilai-Nilai Moral Keagamaan Di Era Globalisasi Melalui Pendidikan Agama." Dharmasmrti: Jurnal Ilmu Agama dan Kebudayaan 18 (2): 50-58.

Suyadi, Suyadi. (2014). "Kepemimpinan Guru dalam Pembentukan Karakter Siswa." Al-Bidayah 6 (1): 115-124.

Tafsir, Ahmad. (2004). Metodologi Pengajaran Agama Islam. Bandung: Remaja Rosdakarya.

Ulumudin, Ikhya. (2016). "Kajian Fenomena Tawuran Pelajar Pendidikan Menengah." Jurnal Ilmiah Mimbar Demokrasi 15 (2)..

UU Sisdiknas. (2003). UU Tentang Sistem Pendidikan Nasional Nomor 20 Tahun 2003. Diambil dari website kemenag: https://kemenag.go.id/file/dokumen/UU2 003.

Wasito, Wasito, and Moh. Turmudi. (2018). "Penerapan Budaya Religius di SD al Mahrusiyah." Jurnal Pemikiran Keislaman 29 (1): 1-22.
Widodo, Sahid Teguh, Sarwiji Suwandi, and Kundhru Saddhono. (2017). "Membangun Moralitas Generasi Muda Dengan Pendidikan Kearifan Budaya Madura dalam Parebasan," 11.

Zedan, Ashraf M., Mohd Yakub Zulkifli Bin Mohd Yusoff, and Mr. Roslan Bin Mohamed. (2015). “An Innovative Teaching Method in Islamic Studies: The Use of PowerPoint in University of Malaya as Case Study." Procedia Social and Behavioral Sciences 182 (May): 543-49. 